\title{
音源の形状による反射・回折現象を伴って放射された音場における 音源位置の探査*
}

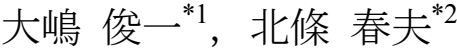

\section{Sound Source Localization for the Source with Sound Reflection and Diffraction Phenomena Caused by the Source Shape}

\author{
Shun-ichi OHSHIMA*1 and Haruo HOUJOH \\ ${ }^{* 1}$ Precision and Intelligence Laboratory, Tokyo Institute of Technology \\ 4259 Nagatsuta-cho, Midori-ku, Yokohama, 226-8503 Japan
}

\begin{abstract}
The noisy sound propagated from the machinery should be reduced to maintain silent environment around the machinery. To achieve such the requirement, the nearfield acoustic holography (NAH) has been developed for sound source localization, and the information of the source locations is utilized to make the machinery silent effectively. While actual machinery has complicated shape and three-dimensional extension of the structure, the NAH provides planer reconstructed images. It is difficult to grasp the three-dimensional source locations with only a planer image. In addition, when the true source is not on the surface of the machinery, the structure of the machinery around the true source might interfere the assumption that the sound propagates in free field. In this study, the model source is used in the experiment, that has a loud speaker, and the baffle plate which is located in front of the loud speaker. The sound propagated from the loud speaker might be reflected and diffracted by the baffle plate. It is proposed that some measurement apertures should be located around the source to solve the three-dimensional source locations, so a compact two-dimensional microphone array is used to move it easily around the source. Source localization is carried out by the NAH with a small number of microphones of the compact array, and requirement of the filtering on the spatial Fourier domain is mentioned. It is proved experimentally that the sound source localization is achieved properly. The experimental results are discussed with numerical results solved by the boundary element method.
\end{abstract}

Key Words : Sound and Acoustic, Measurement, Noise, Nearfield Acoustic Holography, Visualization

\section{1. 緒論}

機械装置から放射される騒音は，更なる低減を図ることが要求されており，その低減化対策を効率的に進める ため, 音源位置を探査する種々の手法が提案されている. そのひとつである近距離場音響ホログラフィ（Nearfield Acoustic Holography, NAH $)^{(1)}$ は, 音場再生結果の空間分解能が音波の波長に依存しない手法として知られている. この手法では, 音源からの距離が一波長以下となる近距離場において複素音圧の二次元分布を計測し，その計測 結果に音波の逆伝播に相当する伝達関数を適用させることで, 計測平面と平行で音源に近接した平面上の強度分 布が再生される．その分布内に現れた極大值の位置が，音源位置に最近傍の点としてみなされ，音源位置の可視 化が可能となる.

このような処理における音波の逆伝播関数は，音波が自由音場中を進行することを想定して定義される．すな わち，音源位置を可視化する再生面と計測平面の間の空間には，空気のような均質な媒質のみの存在が前提であ る．そのような条件を満たすためには，音源表面は平面的な形状であることが理想的である．しかし，実際の機 械装置は立体的で単純ではない形状を有していることが多い. 例えば, 主要な騒音源である原動機の周囲に部分

\footnotetext{
* 原稿受付 2010 年 4 月 12 日

*1 正員, 東京工業大学 精密工学研究所（†226-8503 横浜市緑区長津田町 4259）

${ }^{* 2}$ 正員, フェロー, 東京工業大学 精密工学研究所

E-mail: ohshima.s.aa@m.titech.ac.jp
} 
的なカバーが設置された計測対象であれば，原動機から放射された音波は，そのカバーによって反射や回折の影 響を受ける.この計測対象の近傍で複素音圧分布を計測する場合, 真の音源である原動機から計測平面までの空 間は，そのカバーが含まれるために自由音場とはいえない．

任意形状の音源から放射された音波を計測して音源を探査する手法として，前述のホログラフィに基づく処理 と境界要素法を組み合わせた手法が提案されている(2).ただし, 計測対象である音源形状をあらかじめ境界要素 でモデル化する必要がある. さらに, 計測平面が音源の大きさに対して十分大きく, 無限大とみなせるような計 測条件を確保しなければ，十分な推定精度を確保し難い。これらのことは，実用上の観点からは実現が困難であ り，機械騒音を低減化する要求に対して即応性が期待できない.

そのような背景の下で本研究が目的とするのは，機械装置の放射音を計測してその騒音源を探査する方法につ いて，特に立体的な形状を有する機械装置を対象とした簡易な手法を提案することである．音場の可視化手法は 二次元平面分布計測を基にした NAH を用い，低騒音化対策の実用性や計測システムの可搬性を考慮して，計測 点数や計測領域が限定された条件下で検討する，本論文では，音源モデルを用いた実験結果を示し，その結果を 数值解析によって検証し, 得られた探查結果の因果関係を考察する.

\section{2. 音源位置探査法}

\section{$2 \cdot 1 \quad \mathrm{NAH}$ の定義}

三次元直交座標系で定義される空間において, $z=z_{\mathrm{M}}$ で定められる計測平面上で計測された二次元複素音圧分 布を $\boldsymbol{p}_{\mathrm{M}}(x, y)$ とする. これと平行な $z=z_{\mathrm{R}}$ における平面上の音圧分布 $\boldsymbol{p}_{\mathrm{R}}(x, y)$ は, NAH による自由音場中の伝播 処理によって,

$$
\boldsymbol{p}_{\mathrm{R}}=\mathrm{F}^{-1}\left[\mathrm{~F}\left[\boldsymbol{p}_{\mathrm{M}}\right] \times \boldsymbol{G}\right]
$$

のように再生される. なお, $\mathrm{F}, \mathrm{F}^{-1}$ はそれぞれ $x, y$ 軸に関する二次元フーリエ変換と逆変換を表す. また, $\boldsymbol{G}$ は, 自由音場中の音響伝播を表す伝達関数で,

$$
\boldsymbol{G}=\exp \left\{j \cdot\left(z_{\mathrm{R}}-z_{\mathrm{M}}\right) \cdot \sqrt{k^{2}-k_{x}^{2}-k_{y}^{2}}\right\}
$$

のように, 空間波数領域である $k_{x}-k_{y}$ 平面上で定義される. なお, $j$ は虚数単位であり, $k$ は波数である. また, $k_{x}, k_{y}$ は空間波数成分を表寸座標軸であり, $\boldsymbol{p}_{\mathrm{M}}(x, y)$ が二次元フーリエ変換によって空間波数領域に変換された 分布を定義する.さらに，式(2)において $\Delta z=z_{\mathrm{R}}-z_{\mathrm{M}}$ が負であれば，この伝達関数は音波の逆伝播を表し，音源 位置の可視化を実現する.

この NAH によって音源位置を可視化することとは, 以下のプロセスによって得られる. まず, 音源近傍で $\boldsymbol{p}_{\mathrm{M}}$ なる二次元複素音圧分布を計測し, NAH によって計測平面から音源の方向へ $\Delta z$ だけ逆伝播させて $\boldsymbol{p}_{\mathrm{R}}$ を求める. その再生された $\left|\boldsymbol{p}_{\mathrm{R}}\right|$ において絶対值が極大值として現れる点が，音源の最近傍の点であるとして音源位置を見出 せる.

\section{$2 \cdot 2$ 提案する手法}

前述の NAH による音源位置の可視化結果は，一般的に二次元平面上の分布である.すなわち，音源位置を三 次元的に把握するためには, 複数の再生分布を要する. 一箇所の計測分布から逆伝播距離を変化させて逆伝播再 生を行えば，平行に配列した複数の再生分布が効率的に得られる。しかし，NAH の実用上の制約として，逆伝 播距離 $\Delta z$ が大きくなるほど可視化結果の精度が悪化するため, 逆伝播距離に制限がある. 特に, 本研究で前提と した計測点数が制限される条件下では，その精度悪化が顕著である

そこで本研究では, 機械騒音源の三次元的な位置把握を行う手法として, ステレオ視による方法を提案する. これは, 計測対象周辺で異なる角度から臨むように複数の複素音圧分布を計測し，NAHによってそれぞれの計測 平面から逆伝播処理を行い, 得られた複数の可視化結果をステレオ視のように用いることで, 騒音源の三次元的 
な位置を探査しようとする手法である。また，それぞれの計測結果から NAH によって逆伝播させる距離はおお むね一定とし，可視化結果の精度を維持することが特徵である.

この手法を実用的に用いるためには，可搬性が高い小型の二次元マイクロホンアレーを導入し，複数の複素音 圧分布を容易に計測できるようにすることが有用であると考える．小型のマイクロホンアレーでは，一回の計測 で把握できる音圧分布の範囲が限定される. このことは, NAH の逆伝播処理による可視化結果に, 計算手順に起 因する誤差を招くことが知られており，本研究においても対策を講じる必要がある.

\section{2・3 NAH の推定誤差対策}

NAH を実際に用いる場合は，式(1)，(2)は離散化され，有限領域について適用される，その際，十分な大きさ の計測平面が確保できない場合は, 有限領域の離散フーリエ変換に伴う誤差の影響が無視できないことが知られ ている.この誤差の影響を軽減するための対策として, NAH の計算過程で, 高い空間波数成分を低減するフィル タリングが適用される．近年は，正則化に基づくフィルタ形状決定の自動化が提案され(3), NAH の実用性をさら に高める手段として注目されている，しかし本研究では，従来提案されていた指数フィルタ ${ }^{(4)} の$ 形状を試行錯誤 的に最適化 ${ }^{(5)} し て$ 用いている.

\section{3. 音源モデル周辺の音圧分布計測}

\section{$3 \cdot 1$ 音源モデル}

図 1 は，本実験で用いた音源モデルを示している. 1 辺が $120 \mathrm{~mm}$ の木製立方体バッフルに， $\phi 80 \mathrm{~mm}$ のフルレ ンジスピーカ（FOSTEX FE87）が取り付けられている. スピーカは $2000 \mathrm{~Hz}$ の単一周波数信号で駆動され，スピー カ正面の $100 \mathrm{~mm}$ 離れた位置で音圧レベルが $95 \mathrm{~dB}$ となるようにした. さらに, 立方体バッフルの 1 面と同じ大き さで厚さが $1 \mathrm{~mm}$ のアルミニウム板を, スピーカから $110 \mathrm{~mm}$ 離れた位置に図 2 のように設置した. 本論文では, これを遮蔽板と呼ぶ．スピーカから放射された音波は，遮蔽版により反射や回折の影響を受けて放射するので， 単にスピーカから放射された場合と異なる音場を形成する.

\section{$3 \cdot 2$ 計測条件}

二次元複素音圧分布を計測するためのマイクロホンアレーは, 直径約 $5 \mathrm{~mm}$ のバックエレクトレットコンデン サマイクロホンを $8 \times 8$ 本備え，これらを $50 \mathrm{~mm}$ 間隔の格子状に配置している ${ }^{(5)}$. 寸なわち，二次元分布計測の範

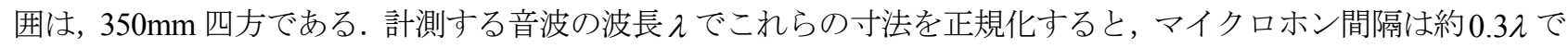

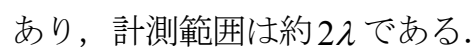

図 3 は, 音源モデルとマイクロホンアレーの 3 通りの位置関係を $z-x$ 平面上に示している. 音源モデルのスピー カ位置は原点にあり, 遮蔽板はスピーカから $z$ 軸の正方向に位置している. マイクロホンアレーで計測する平面 の法線は, $z-x$ 平面と平行であり, 図 3 の各図下方に, 計測平面位置を表す二重線と, アレーの一辺に相当する

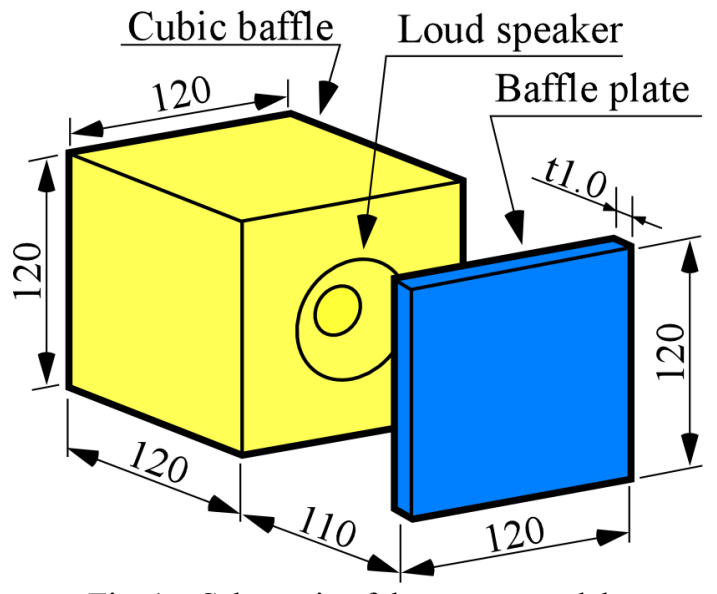

Fig. 1 Schematic of the source model.

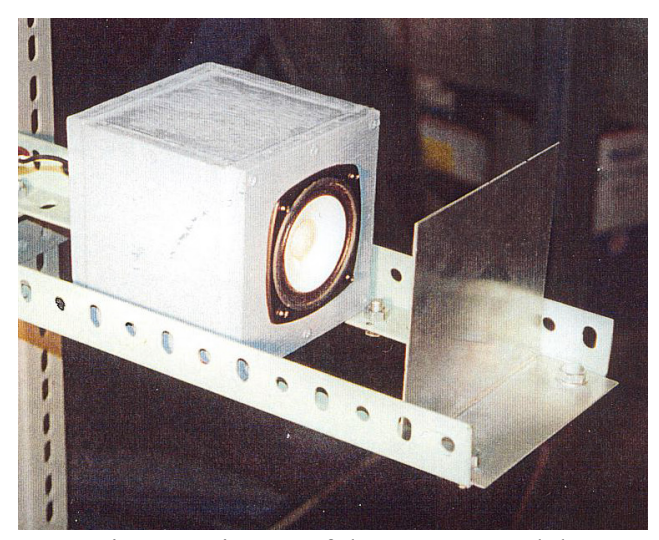

Fig. 2 Picture of the source model. 
8 本のマイクロホンが描かれている．この計測平面は，スピーカ位置から $200 \mathrm{~mm}$ 離れており，音源モデルを 3 通 りの異なる角度で見込む位置である。本論文ではそれぞれを計測位置(i), (ii), (iii)と呼ぶ。スピーカとマイクロ

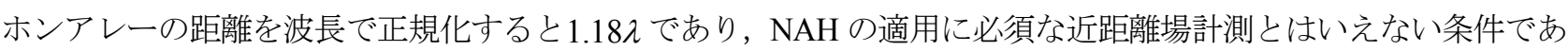
る.しかし，計測対象の立体的形状のために，マイクロホンアレーを常に波長以下の距離にまで近づけられない ことは，実用上の制約として想定される計測条件である.

\section{$3 \cdot 3$ 計測された複素音圧分布}

図 3 に示した 3 箇所にそれぞれマイクロホンアレーを設置して, 複素音圧分布を計測した結果を図 4 に示す. 図 4 では複素量分布を振幅と位相の分布に分け，それぞれ等高線で示している．振幅分布では，最大值の $10 \%$ 毎 の等高線を描いており，90\%を表す等高線は太線で描いている. 位相分布は， $0.25 \pi \mathrm{rad}$ 間隔で等高線が描かれて いる．また，分布内にはマイクロホン位置を表す白丸と，計測平面の背後から音源方向を見たときの音源モデル 外形が描かれている.

図 4(a)に示した計測位置(i)では, 振幅の極大值が平面の中心とその上方に現れている.この計測位置からスピー カを直接視認することはできないが，中心の極大值は，遮蔽板背後にあるスピーカの軸上にある．しかし，この 計測結果の極大值位置から音源位置を判断しようとすると, 遮蔽板が音源であると誤認する可能性がある.また, 遮蔽板上方の極大值は, 遮蔽板背後から音波が回り込んできた影響が考えられるが, 遮蔽板下方に現れないのは, 図 2 に示すように，遮蔽板を支えるアングル構造材が音波を遮った影響が予想される.

一方, 図4(b)に示した計測位置(ii)では, 音源モデル周辺でマイクロホンアレーを移動させたことによってスピー カが直視できるようになり，その位置に極大值が現れている．すなわち，スピーカから放射された音波が遮蔽板 の影響を大きく受けることなく，計測平面に到達しているといえる.

図 4(c)の計測位置(iii)のときは，極大值が遮蔽板位置で，かつスピーカ位置とは反対側の面に現れている．この ことは，図 4(a)の計測位置(i)の結果と合わせたときに，音源が遮蔽板の外側にあるという誤認を助長してしまう ことになり, 適切ではない.

位相分布は, いずれの計測位置においてもスピーカ位置を中心とした同心円状であり, 振幅分布と比較すれば, 比較的単純な分布であることがわかる.

図 4 に示した複素音圧分布の計測結果から音源位置を見出そうとする場合，音源に最近傍の位置において，振 幅分布では極大值が現れ，位相分布では同心円の中心となる.しかし，図 4 の計測結果から総合的に判断しよう とした場合に, 真の音源がスピーカ位置に存在することを断定し難い. すなおち, 次章で示す NAH による逆伝 播処理を要する.

\section{4. 音源位置の探査結果}

\section{4-1 音源モデル周辺の再生結果}

図 4 に示した複素音圧分布の計測結果を基に, NAH による逆伝播処理によって, 音源モデルに近い再生面上の 分布を再生した結果の振幅分布を図 5 に示す. これらの分布は, 図 4 の振幅分布と同様な等高線で示している. また，再生面の位置は，図 3 において，計測平面と平行で音源モデルにより近い位置に描かれている太破線で示 している. それぞれの逆伝播距離は，(i)と(ii)については $80 \mathrm{~mm}$ とし，(iii)は $100 \mathrm{~mm}$ とした。れらの逆伝播距 離はそれぞれ $0.47 \lambda, 0.59 \lambda$ に相当し，逆伝播距離がマイクロホン間隔の 2 倍である $0.59 \lambda$ を超えない範囲で，再 生面位置が音源モデル外形の最近傍となるようにした。 なお，逆伝播距離の制限值は，本計測条件下で NAH に よる逆伝播再生を有効にするために，別途数值解析的検討から得られた值(5)である.

図 5(a)に示した計測位置(i)から逆伝播させた再生結果では，図 4(a)で見られた計測分布中央の極大值が消えて いることから，遮蔽板が音源として振舞っていないと判断できる．また，遮蔽板周辺の等高線が密になっている ことから，全体的な分布の傾向は，頂上が平坦な山状の分布である．このことは，遮蔽板背後から放射された音 波が，遮蔽板によってマスキングされているように観察される.

図 5(b)の計測位置(ii)から逆伝播させた再生結果では，直視可能なスピーカ位置に鋭い極大值が現れている.こ れは，真の音源位置を適切に可視化できた妥当な結果である. 


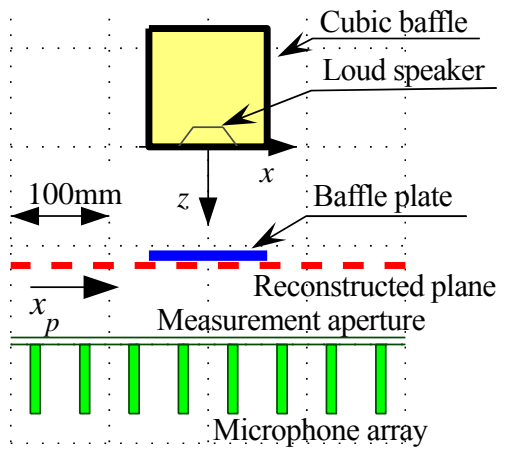

(a) Measuring position (i).

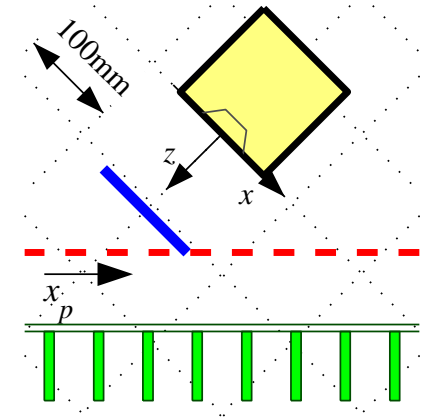

(b) Measuring position (ii).

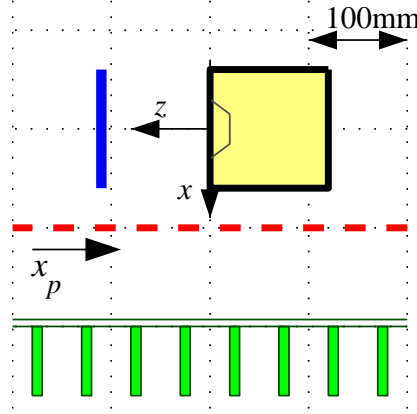

(c) Measuring position (iii).

Fig. 3 Layouts of the experimental apparatus.

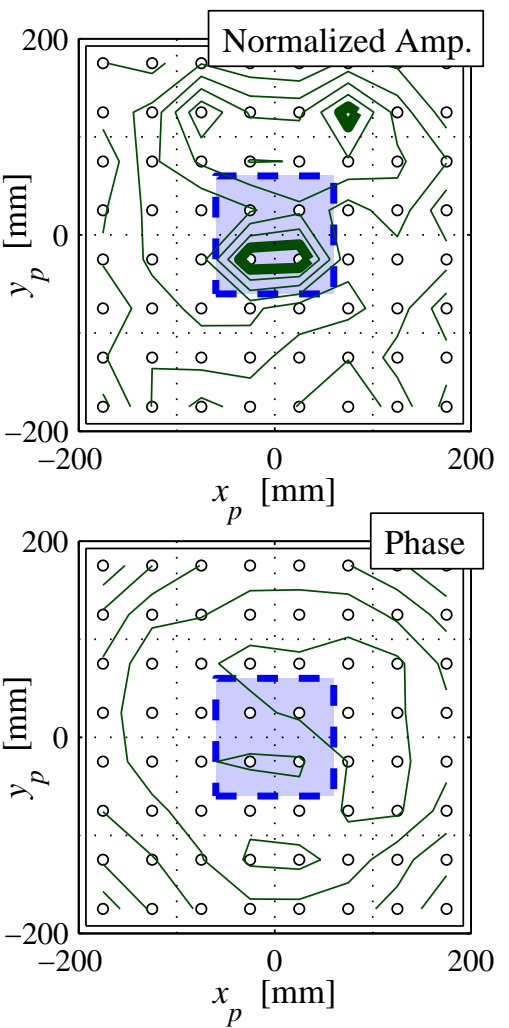

(a) Measuring position (i).
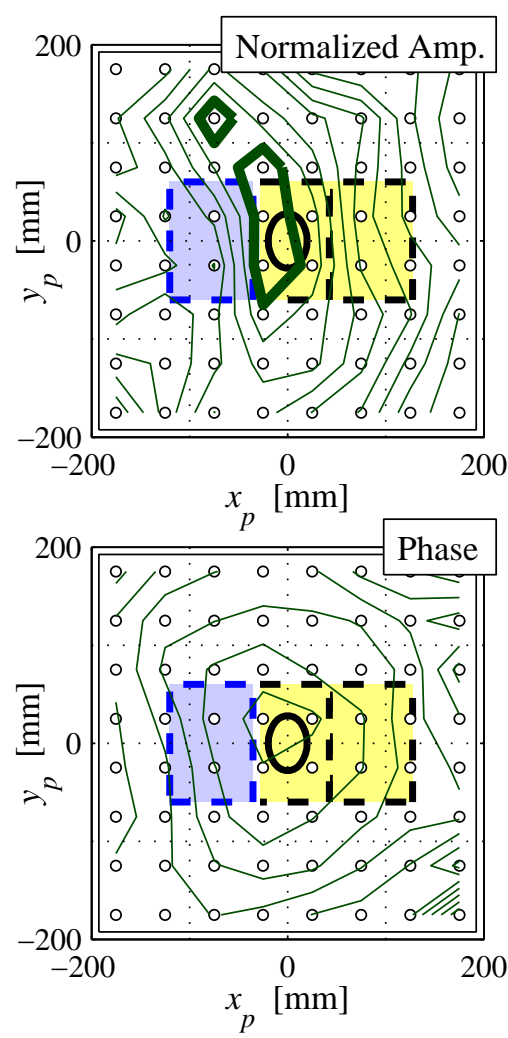

(b) Measuring position (ii).

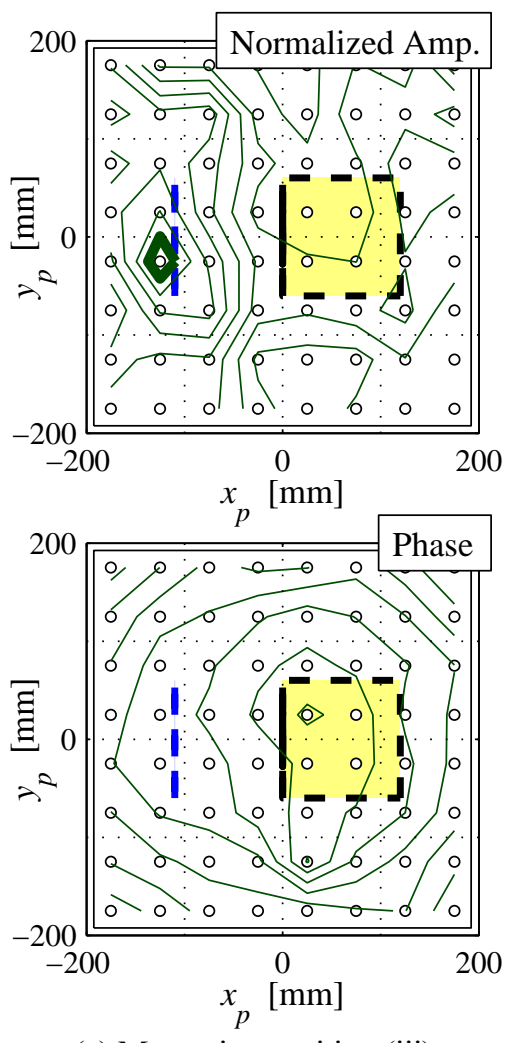

(c) Measuring position (iii). Fig. 4 Contour maps of the measured complex sound pressure distributions.
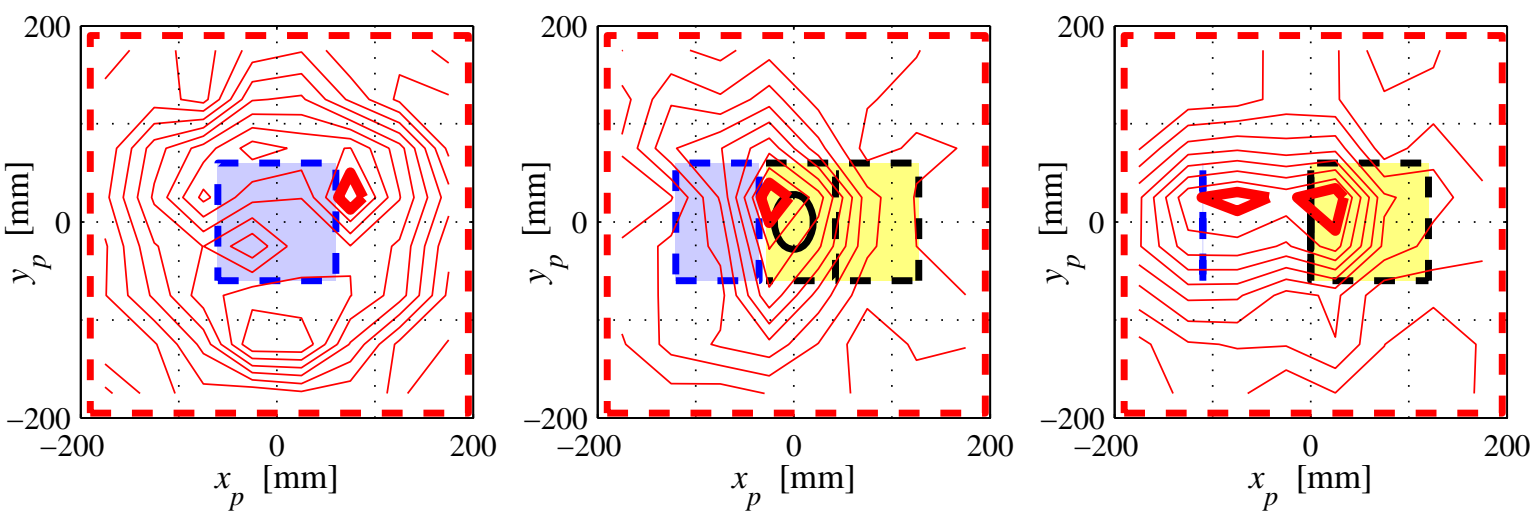

(a) Reconstructed from position (i).

(b) Reconstructed from position (ii). (c) Reconstructed from position (iii). Fig. 5 Contour maps of the reconstructed distributions by the NAH. 
一方，図 5(c)の可視化結果には，遮蔽板とスピーカの両方に音源位置を示す極大值が現れている. スピーカ位 置に現れた極大值は真の音源を意味するが，遮蔽板に現れた極大值は，遮蔽板の反射による虚像であると考えら れる.

\section{$4 \cdot 2$ 計測平面を近づけることの効果}

図 5(c)の可視化結果に現れた 2 つの極大值を区別するために，マイクロホンアレーを音源モデルに近づけて同 様の再生を試みた. その結果を図 6 に示す. 図 6(a)では, マイクロホンアレーを計測位置(iii)から音源モデルに $50 \mathrm{~mm}$ 近づけており，図 6(b)では計測位置(iii)から $100 \mathrm{~mm}$ 近づけ，それぞれ複素音圧分布を計測した。再生面の 位置は，それぞれ $80 \mathrm{~mm} ， 100 \mathrm{~mm}$ だけ逆伝播させた位置にある．音源モデルとそれぞれの平面の位置関係は，図 6 左側に示している.

複素音圧振幅の計測結果は，図 6 中列の二重線で囲まれた等高線で示されている。これらの分布では，遮蔽板 位置に強い極大值が存在しており，特に図6(b)では，音源モデル外形から 40mm しか離れていない計測位置にも かかわらず，スピーカ位置に強い極大值が現れていないことから，計測のみでは真の音源位置を見出し難い.

計測された複素音圧分布から NAH によって求められた可視化結果は，図 6 右側の破線で囲まれた等高線で示 されている. いずれの再生結果においても, 音源位置を示す極大值がスピ一カ位置においてより強く得られてお り，正しく音源位置可視化が実現できていることがわかる．図 6(b)の結果においては，再生面が音源モデル内部 を横断しており，NAH による逆伝播経路の空間に音源モデル筐体が含まれていることから，式(2)に示した自由 音場中の伝播関数を用いることの前提が満たされていない.しかし，この結果が示すように，実用上は真の音源 であるスピーカ位置を可視化できていることから，本手法は有用であるといえる.

なお，図 5(c)に示した NAH による再生結果は，同じ平面上を計測した音圧振幅分布である図 6(b)中列の二重線 で囲まれた等高線と比較すると, スピーカ位置の極大值に関して異なる傾向を示している. すなわち，NAHの結 果が実際の音圧分布とは異なる分布を再生している.この原因は，次章において数值解析によって考察する.
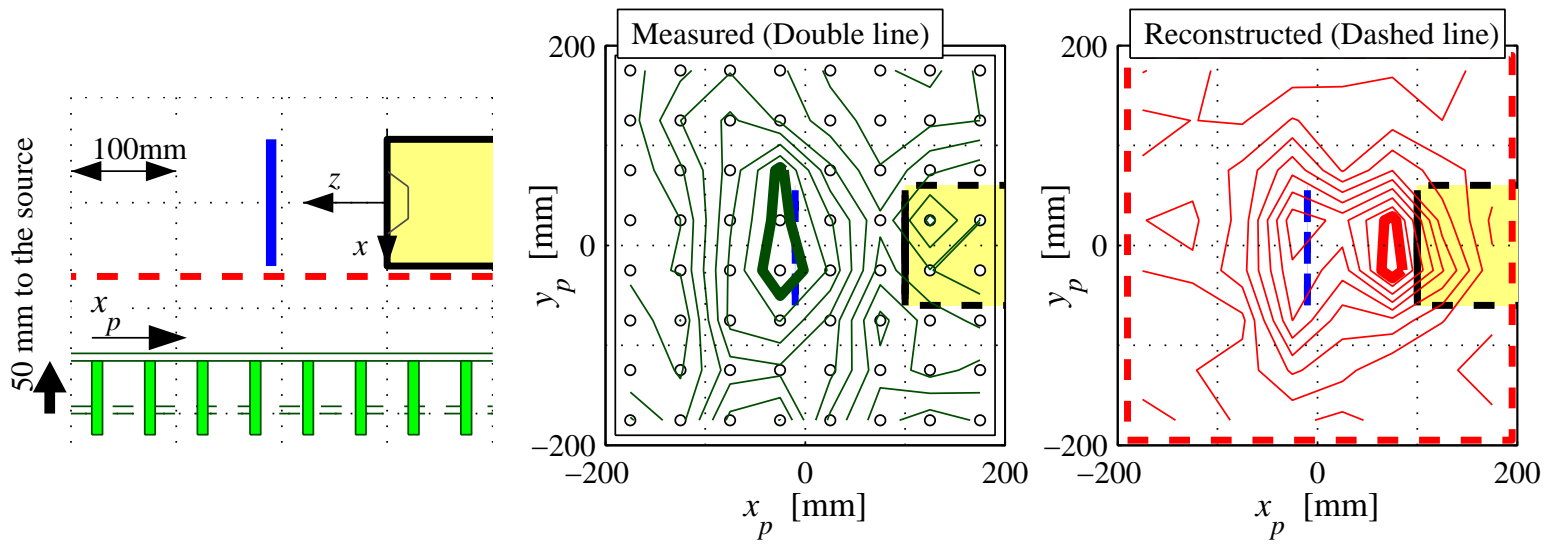

(a) Measured and reconstructed results, $50 \mathrm{~mm}$ moved to the source model from the position (iii).
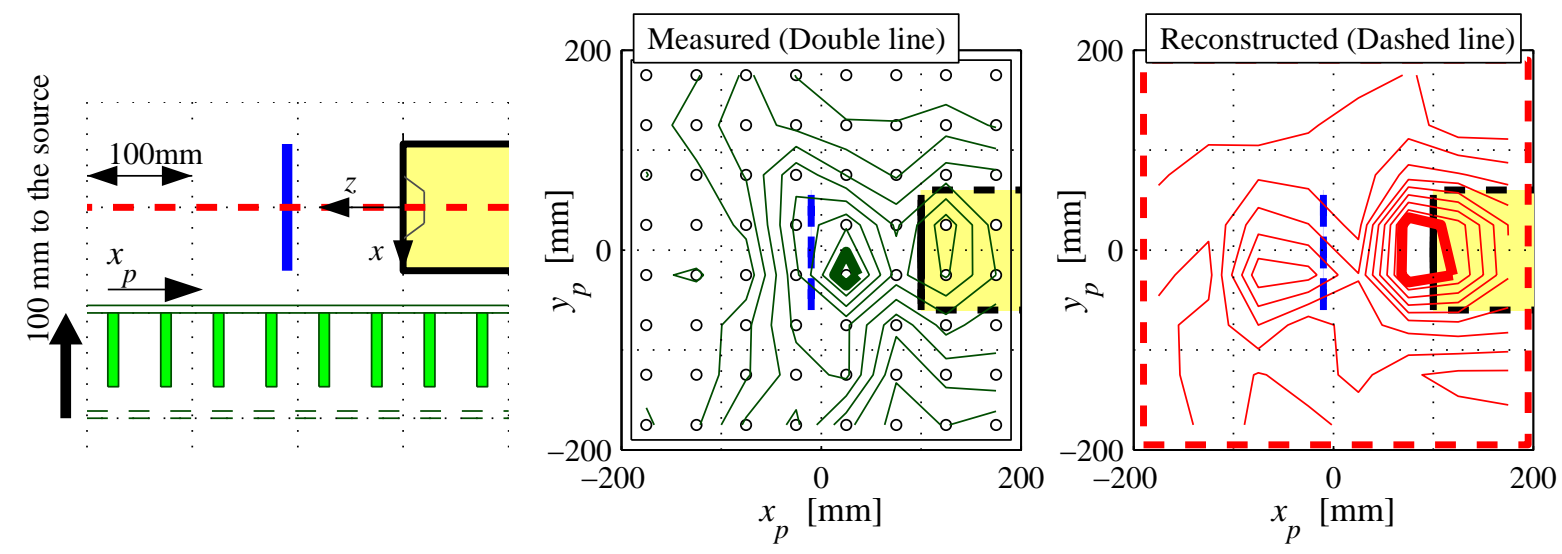

(b) Measured and reconstructed results, $100 \mathrm{~m}$ moved to the source model from the position (iii).

Fig. 6 Contour maps of the measured and reconstructed distributions of the amplitudes. 


\section{5. 数值解析による実験結果の検証}

\section{$5 \cdot 1$ 検証の目的}

NAH の逆伝播処理によって求められる再生面上の分布は, NAH が自由音場中で理論的に実行されれば厳密で ある. しかし，実際には演算が離散化されている上に，空間波数領域において指数フィルタが適用されている. これらのことは, 図 5(c)の再生結果が図 6(b)の計測結果と異なっていたことの原因になり得る. そこで本章では, 実験における音場を境界要素法によって数值解析的に求め, 指数フィルタの影響を検証する. また，本検討で適 用した手法の，音源の探査法としての有効性を考察する.

\section{$5 \cdot 2$ 数值解析の概要}

本検証で導入した境界要素法では，まず，音源モデルの立方体バッフル表面を 1296 の一定要素(6)で分割した. スピーカのダイアフラムに相当する境界要素には，一定の振動速度を初期条件として与え，その他の境界要素を 振動しない剛体面として定義した．音源モデルの遮蔽板は，厚みのない要素として取り扱い， 1 層の 288 要素に 分割した. さらに，薄板まわりの音波の反射・回折問題を解くために用いられる法線微分型の方程式(7)を適用す るために，遮蔽板表裏の音圧差分值を変数とした。

要素間の幾何学的関係等から，離散化された Helmholtz 境界積分方程式をたて，音源からの音響放射によって 形成される音場を解き，二次元マイクロホンアレーが設置される平面上や，NAH の逆伝播処理によって求められ る再生面上の複素音圧分布を求めた。 なお，方程式を解くための逆行列計算には，MATLAB を用いた.

\section{$5 \cdot 3$ 数値解析結果}

本検証では, 前章に示した実験結果に基づいた NAH の再生結果のうち, 2 つの条件について数值解析解と比較 する. 1 つは, 図 5(a)に示されている再生結果であり，もう1つは，図 5(c)に示されている再生結果である. それ らの再生位置における複素音圧分布の数值解析解を, 図 7 に示寸. これらは, 複素音圧の振幅分布を図 5 と同様 な等高線で示し，さらに， $y_{p}=0$ 上の振幅と位相を別途表示している.

図 7(a)については， $y_{p}=0$ 上の複素音圧を簡易な実験で計測したところ，振幅と位相がそれぞれ図 8 のように 得られたことから, 解析解が十分な精度で得られているといえる. また, 図 7(b)については, 図 6(b)中列に示し た，実測された振幅分布と比較すると，解析解が実測結果と一致しており，解析結果は妥当である. すなわち， 図 7 の結果は, NAHによる再生面位置を実際に計測して得られる分布と一致する.

その上で図 7 の結果とそれぞれに対応寸る NAH の再生結果と比較すると, NAH の結果は実際の音場と異なる ことがわかる. 図 7(a)の結果には，NAH の再生結果である図 5(a)には現れていなかった大きな極大值が遮蔽板中 央に現れている. また, $y_{p}=0$ 上の振幅を見ると, 遮蔽板周辺で一旦極小值を示しており, 位相は遮蔽板周辺で ステップ状にシフトしていることがわかる．境界要素法においては，スピーカ正面に挿入された遮蔽板が振動し ない剛な平面として取り扱われるとき，その位置の粒子速度を零にするような仮想の音源として振舞う．そのた め, 境界要素法の解には，スピーカを音源とする音場と，遮蔽板を仮想の音源とする音場が合成された結果が現 れている. 寸なわち, この複素音圧分布に現れた大きな極大值は, 分布を求めた平面が遮蔽板直近であるために, 遮蔽板の仮想音源としての振舞いが強く現れたといえる.

図 7(b)に示した結果は, 単に音源モデルに近づいた計測を行ってもスピーカ近傍に極大值が得られないことが, 数值解析でも裏付けられたといえる。この結果における極大值が，スピーカ位置直近ではなく遮蔽板の方に現れ た根拠は，図 9 のように，スピーカ位置から放射された音波が観測点に直接到達寸る経路と，遮蔽板において反 射した上で到達する経路を，それぞれ波長で正規化して比較することで幾何学的に理解することができる. 表 1

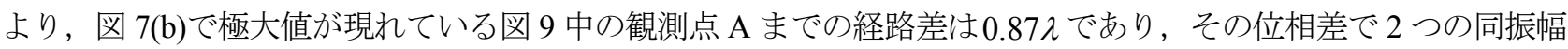
の音波を合成すると，元の振幅のおよそ 1.84 倍となる. 一方，スピーカ直近の観察点 $\mathrm{B}$ ではそれがおよそ 0.44 倍となる.すなわち, スピーカに最近傍の観測点 $\mathrm{B}$ には極大值が現れ難く, 必然的に観測点 $\mathrm{A}$ に大きな極大值が 現れる. 

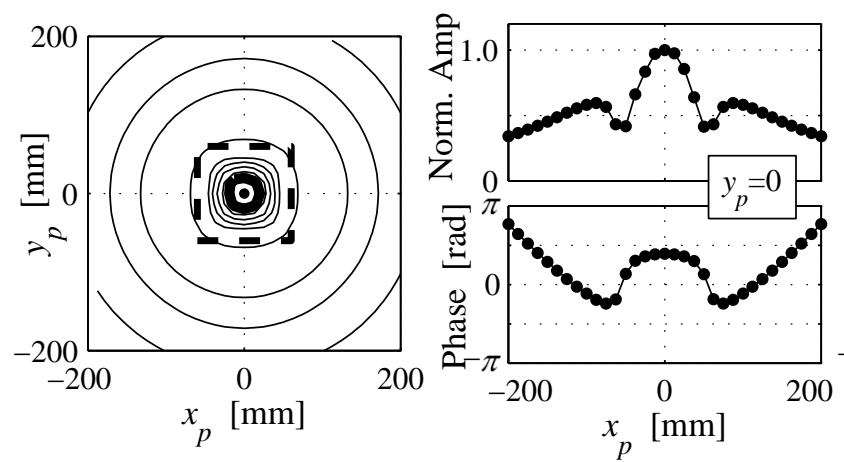

(a) True distribution at the position reconstructed from position (i), different from the result shown in fig 5(a).
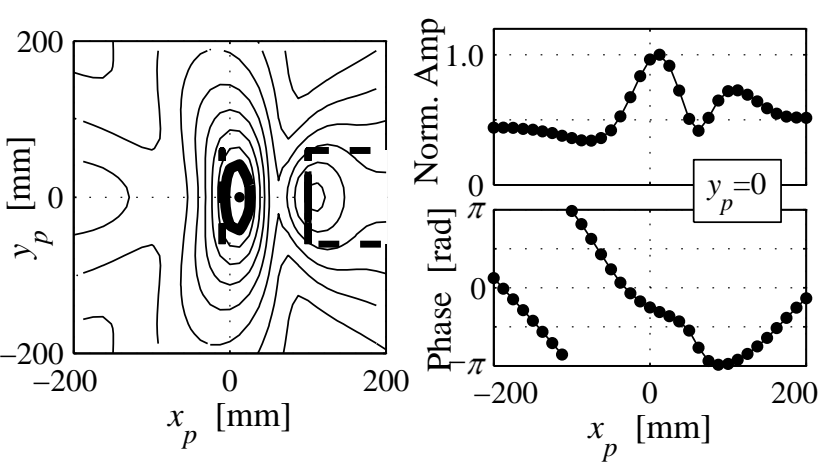

(b) Equivalent to the measured distribution shown in fig. 6(b).

Fig. 7 Contour maps of the numerical results of the sound pressure distributions.
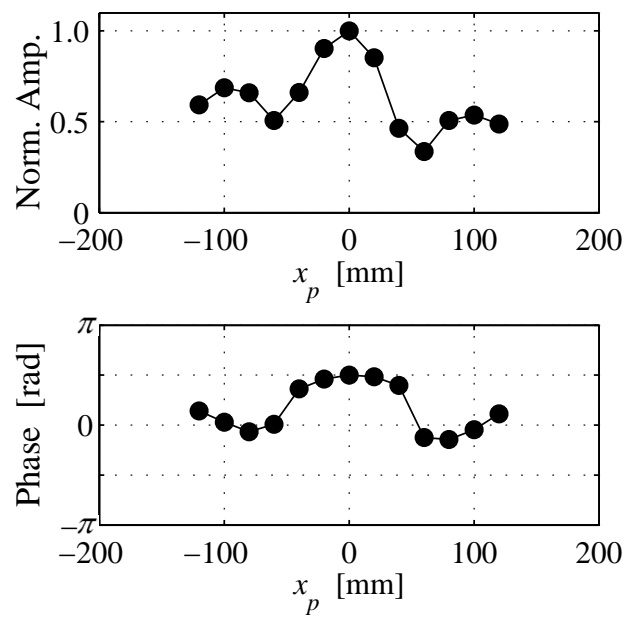

Fig. 8 Experimental result to verify the numerical result shown in fig 7(a).

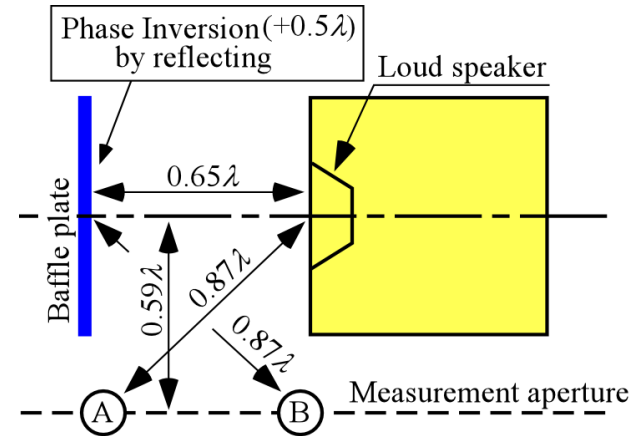

Fig. 9 Representation of propagating distances.

Table 1 List of propagating distances and differences.

\begin{tabular}{c|ccc} 
& Direct path & Reflecting path & Difference \\
\hline $\mathrm{A}$ & $0.87 \lambda$ & $(0.65+0.5+0.59) \lambda$ & $0.87 \lambda$ \\
\hline $\mathrm{B}$ & $0.59 \lambda$ & $(0.65+0.5+0.87) \lambda$ & $1.43 \lambda$ \\
\hline
\end{tabular}

\section{$5 \cdot 4$ 波数空間フィルタの適用}

図 7 の数值解析解に, NAH で用いている指数フィルタを適用した結果を図 10 に示す.フィルタ適用の方法は, 数值解析解を二次元離散フーリエ変換によって空間波数領域の分布に変換し，指数フィルタを適用した後に，逆 変換によって元の空間座標に戻した。ただし，離散フーリエ変換において，サンプリング領域や離散点数の不足 に伴う誤差の影響を避ける必要がある。そこで， $3.2 \mathrm{~m} \times 3.2 \mathrm{~m}$ の十分な大きさの領域内を $256 \times 256$ 点で離散化し た複素音圧分布を境界要素法によって求め, 離散フーリエ変換を適用した. これは, 実験条件に対して 8 倍の大 きさであり，4 倍の分解能を有する.

困 10(a)は，NAH の再生結果である図 5(a)と同様であることが明らかである。図 10(b)は，実測した結果である 図 6(b)中列の二重線で囲まれた等高線や，その数值解析解である図 7(b)には現れなかったスピーカ位置の極大值 が明確に現れている. NAH の再生結果である図 5(c) と比較すると, 遮蔽板位置における極大值に関しては相対的 な大きさが異なっているものの, おおむね同様な傾向の分布が得られている. 図 10 の結果は, いずれも実際の複 素音圧分布と異なり，音源位置の可視化に有用な結果が導かれているといえる.

この検討によって，NAH の再生結果が現実の音場分布と異なる原因が，NAH で適用している指数フィルタで あるといえる. その指数フィルタの適用によって, 音波の波数を上回るエバネッセント波成分が大きく減衰させ られている(5). 寸なわち, 本来, NAH の逆伝播処理による音源位置の再生は, 音波が遠距離場に伝播してゆく過 程で急速に減衰するエバネッセント波成分を適切に取り扱うことによって，音源直近の詳細な像が得られること を特徴としているが，本検討の場合はその成分を除いている．一方，音源モデルの遮蔽板は，その位置の粒子速 度を打ち消して零にするような仮想の音源として振舞う。遮蔽板はそれ自身が音源ではないので，この仮想音源 


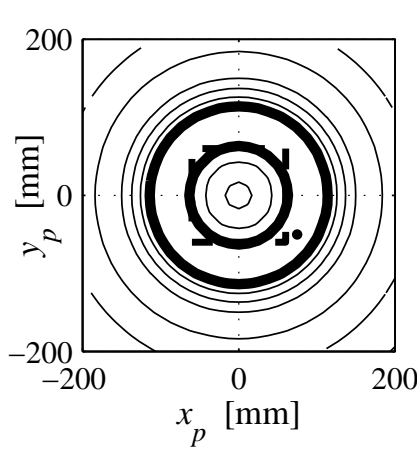

(a) Equivalent to the result shown in fig. 5(a).

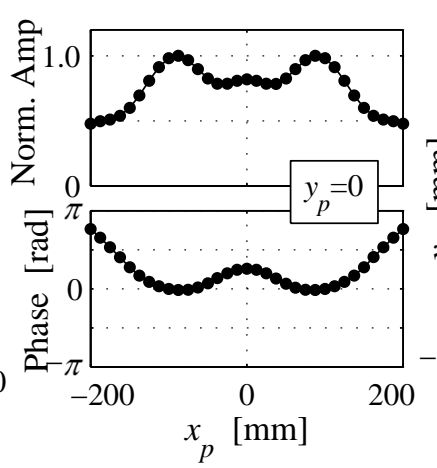

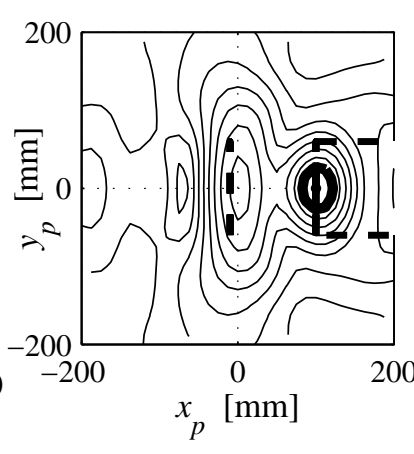

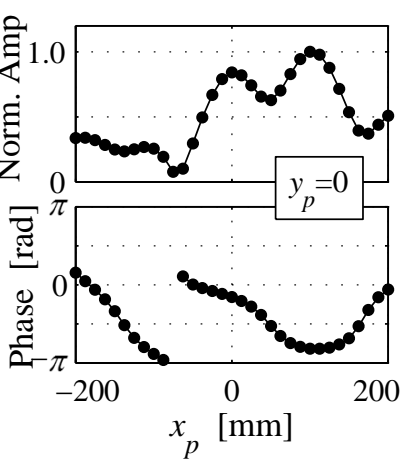

(b) Equivalent to the result shown in fig. 5(c).

Fig. 10 Contour maps of the numerical results solved with the exponential filters.

としての寄与は遠距離場へ伝播せず，音源直近の局所的なものである．すなわち，この寄与はエバネッセント波 成分が主体であると考えられる. その影響が, NAH の推定誤差対策で用いられた指数フィルタによって抑えられ たために，遠距離場へ伝播する真の騒音源として，スピーカからの寄与が可視化結果に残ったといえる.

NAH の逆伝播処理に指数フィルタを適用することで, 現実の音場分布を正しく再生することはできない. しか し，指数フィルタでエバネッセント波成分を減衰させたことによって，真の音源ではない機械装置筐体が，音源 直近で仮想音源のように振舞う影響を除去できたといえる，すなわち，機械騒音の低減を目的とした音源位置の 探査であれば，本来は計測条件が限定された NAH の実現に不可欠な指数フィルタの効果によって, 副次的に実 質の騷音源を見出すことができるといえ，機械装置の低騷音化対策に実効的であるといえる.

\section{6. 結 論}

本論文は，機械装置の低騒音化対策に活用できる音源探査手法を実験的に検討した．それは，立体的な形状を 有する音源モデルを導入し，反射や回折を伴って放射された音波を計測点数などが限定された条件下で計測し， 近距離場音響ホログラフィを基にした音源位置の再生によって, 真の音源位置を見出すことを目的とした検討で ある. また，その結果を数值解析結果と比較することで考察した。

本論文で論じた考察によって得られた結論は，以下のとおりである.

(1) 機械騒音源の可視化を実用的に行うために, マイクロホン数を限定して可搬性を高めた二次元アレーを 構築し，それを計測対象の周辺で移動させながら音源を探査することを提案した.

(2) 計測対象周辺で見込む角度を変化させた複数の計測位置を設けることで，音源位置の三次元的な把握が 可能であり，より詳細な探査は，計測位置を近づけることで可能であることを，実験的に明示した．

（3）近距離場音響ホログラフィにおける指数フィルタの適用によって, 真の音場分布とは異なる分布が再生 されるが，機械装置の形状に依存して音波の反射や回折を引き起こす要因が副次的に除去でき，真の騒 音源が見出せる可能性を示した.

\section{文献}

(1) Williams, E. G., Fourier Acoustics: Sound Radiation and Nearfield Acoustical Holography (1999), Academic Press.

(2) Bai, M. R., "Application of bem (boundary element method)-based acoustic holography to radiation analysis of sound sources with arbitrarily shaped geometries", The Journal of the Acoustical Society of America, Vol. 92, No. 1 (1992), pp. 533-549.

(3) Williams, E. G., "Regularization methods for near-field acoustic holography", The Journal of the Acoustical Society of America, Vol. 110, No. 4 (2001), pp. 1976-1988.

(4) Velonesi, W. A. and Maynard, J. D., "Nearfield acoustic holography (NAH): II. Holographic reconstruction algorithms and computer implementation", The Journal of the Acoustical Society of America, Vol. 81, No. 5 (1987), pp. 1307-1322. 
(5) Houjoh, H. and Ohshima, S., "Some problems of near field holographic measurement with a limit sized handy 2-D array for an on-site machine noise assessment", Proceedings of Inter-Noise 2001 (2001), pp. 2089-2094.

(6) Ciskowski, R. D. and Brebbia, C. A., Boundary Element Methods in Acoustics (1991), Computational Mechanics, Southampton.

(7) Terai, T., “ON CALCULATION OF SOUND FIELD AROUND THREE DIMENSIONAL OBJECTS BY INTEGRAL EQUATION METHOD”, Journal of Sound and Vibration, Vol. 69, No. 1 (1980), pp. 71-100. 